Edu Consilium: Jurnal BK Pendidikan Islam

Vol. 3, No. 1, 2022, hlm. 51-65

DOI: $10.19105 /$ ec.v1i1.1808

ISSN 2503-3417 (online)

ISSN 2548-4311 (cetak)

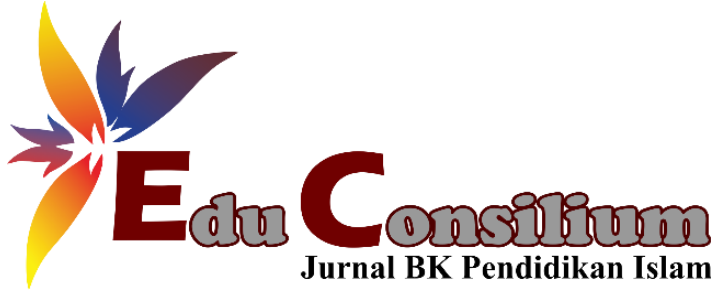

\title{
FANATISME DAN KONFORMITAS KOREAN WAVE PADA REMAJA
}

\author{
${ }^{1}$ Anisa Agustanti \\ ${ }^{1}$ Program Studi Magister Psikologi, Universitas Mercubuana Yogyakarta, Indonesia \\ anisaagustanti@gmail.com
}

\begin{abstract}
Keywords: $\quad$ Korean Wave is a term given to the spread of Pop culture in Indonesia at this time.

Fanaticism; The Korean phenomenon has hit the younger generation, especially Indonesian

Conformity; $\quad$ teenagers, which has many negative impacts. Teenagers must be able to mentally

Youth revolutionize and also become agents of change to make Indonesia better, and a part of the period of a complete life journey, namely part of a society that can always make a lot of good contributions, be exalted, optimistic and intelligent. This study uses the Systemic Literature Review method by collecting as many sources as possible, both journals, books related to the research topic. The results of the study show fanaticism and conformity of the Korean wave in adolescents that form loyalty behaviors that are members of groups or communities, the support and attention shown, and beliefs or views that stand out about the object. Teenagers who like the Korean Wave can be tried not to behave in fanaticism and negative conformity such as extreme behavior towards idols, create a community with the same characteristics of liking on the Korean wave and make fanatical behavior and positive conformity of teenagers so that society can accept that.
\end{abstract}

\begin{tabular}{ll}
\hline \hline & Abstrak \\
\hline Kata Kunci: & Korean Wave sebuah istilah yang diberikan untuk tersebarnya budaya Pop di \\
Kanatisme; & Indonesia saat ini. Fenomena Korea melanda generasi muda terutama remaja \\
Konformitas; & Indonesia yang memiliki banyak dampak negatif. Remaja harus bisa merevolusi \\
Youth & mental dan juga menjadi agent of change untuk membuat Indonesia semakin baik, \\
& dan sebuah bagian masa dari perjalanan kehidupan yang utuh yaitu bagian dari \\
& masyarakat yang senantiasa bisa melakukan banyak kontribusi kebaikan, \\
& ditinggikan, optimistis dan pandai. Penelitian ini menggunakan metode Systemic \\
& Literatur Review dengan cara mengumpulkan sebanyak mungkin sumber baik itu \\
& jurnal, buku yang berkaitan dengan topik penelitian. Hasil penelitian menunjukkan \\
& fanatisme dan konformitas Korean wave pada Remaja yang membentuk perilaku \\
& kesetiaan yang tergabung dalam kelompok atau komunitas, dukungan dan perhatian \\
& yang ditunjukkan , dan keyakinan atau pandangan yang menonjol tentang objek \\
& Remaja yang menggemari Korean Wave bisa diupayakan tidak berperilaku fanatik \\
& dan konformitas yang negatif seperti berperilaku ekstrim kepada idola, membuat \\
& komunitas dengan ciri khas kegemaran yang sama pada Korean wave dan jadikanlah \\
& perilaku fanatik dan konformitas remaja yang positif agar masyarakat dapat \\
& menerima hal tersebut. \\
\hline CEdu Consilium: Jurnal Bimbingan dan Konseling Pendidikan Islam \\
Institut Agama Islam Negeri Madura, Indonesia
\end{tabular}




\section{PENDAHULUAN}

Negara Korea telah berhasil menyebarkan produk budaya populernya ke dunia internasional yang dikenal dengan budaya Pop Korea (K-Pop) dengan istilah 'Korean Wave' atau 'Hallyu', Proses penyebaran budaya Korea tidak bisa dilepaskan dari keberadaan media massa seperti internet, Facebook, twitter, youtube, dan sebagainya, bahkan bisa dikatakan bahwa media massa adalah saluran utama penggerak Korean Wave (Purwanti, 2013). Tersebarnya Korean wave melalui berbagai cara juga dipermudah dengan akses internet dan banyaknya media sosial yang memudahkan siapapun dapat mengakses informasi yang tersedia dalam berbagai bahasa (Rinata \& Dewi, 2019) keterbatasan akan perbedaan bahasa akhirnya juga dapat diatasi dengan makin banyaknya fans ataupun non-fans yang membuka jasa terjemah subtitle K-drama atau pun Musik K-pop. Dengan begitu, orang yang menaruh minat pada budaya pop Korea Selatan akan semakin mudah dan semakin mencintainya.

Sebutan "Fans Korea" menjadi satu label bagi orang-orang yang menaruh minat pada segala bentuk budaya yang dibawa oleh Korea Selatan. Akun media sosial penggemar K-pop digunakan untuk mengakses berbagai informasi tentang idola mereka. Dikutip Dari survei kumparan, 56 persen fans K-pop menghabiskan waktu 1-5 jam berselancar di media sosial untuk mencari tahu segala informasi tentang idola mereka. Sebanyak 28 persen fans bahkan menghabiskan 6 jam lebih di dunia maya untuk melihat berbagai aktivitas sang idola (Kumparan, 2017).

Generasi muda yang mulai tertarik dengan berbagai hiburan yang disajikan oleh Korean Wave, tidak menutup kemungkinan akan timbul beberapa sikap fanatisme terhadap Korean Wave tersebut. Yang kemudian, sikap fanatisme tersebut akan mempengaruhi pola atau gaya hidup dari generasi penggemar Korean Wave (K. A. Putri et al., 2019). Penggemar Korean Wave pada komunitas fans-club akan memberikan dukungan kepada idolanya dan sesama fans akan setia mendampingi idolanya, hal ini karena perilaku konformitas yang ditunjukkan oleh kelompok tersebut. (Widarti, 2016). Walaupun remaja memiliki fans-club berbeda-beda tetapi sesama penggemar K-Pop mereka akan saling memberikan dukungan. Terdapat konformitas dari orang-orang sekitar yang menyukai K-Pop sehingga sedikit atau banyak se-seorang akan mulai tertarik pada dunia K-Pop itu sendiri. Lebih lagi yang menjadi pasar dari musik ini kebanyakan adalah kalangan remaja, dimana dalam masanya mereka akan lebih cenderung konform pada teman-temannya.

Remaja adalah usia yang paling dibanggakan, bukan hanya memperhatikan pertumbuhan, perkembangan serta perubahan biologis remaja saja, namun yang lebih penting 
mempersiapkan remaja menjadi generasi yang paham dalam mengintegrasikan nilai-nilai akhlak, iman, dan pengetahuan. (Jannah, 2017) Remaja harus mampu mengembangkan seluruh potensi baik yang ada dalam dirinya sehingga mampu melewati perkembangannya tanpa stres dan penuh kebimbangan. Adapun tujuan yang hendak dicapai adalah bagaimana perkembangan remaja mampu melewati fase kritis dengan tidak mengalami tekanan yang berat, sehingga berdampak pada perilaku negatif . Studi ini menelaah beberapa kajian teori dan menyesuaikan dengan fenomena yang terjadi saat ini, sehingga menunjukkan bahwa remaja saat ini sulit menjalankan tugas-tugas perkembangannya jika tidak didukung oleh lingkungan yang sehat.

Masa remaja adalah suatu masa peralihan yang sering menimbulkan gejolak. Menurut Hurlock (1994) remaja berasal dari istilah adolescence yang memiliki arti tumbuh untuk mencapai kematangan, baik mental, emosional, sosial, dan fisik. Pada masa ini ditandai dengan adanya perkembangan yang pesat pada individu dari segi fisik, psikis dan sosialnya. Menurut Hurlock (1994: 207) pada masa ini pula timbul banyak perubahan yang terjadi, baik secara fisik maupun psikologis, seiring dengan tugas-tugas perkembangan yang harus dipenuhi oleh remaja. Berkaitan dengan hubungan sosial, remaja harus menyesuaikan diri dengan orang di luar lingkungan keluarga, seperti meningkatnya pengaruh kelompok teman sebaya (peer group). Kuatnya pengaruh kelompok sebaya terjadi karena remaja lebih banyak berada di luar rumah bersama dengan teman sebaya sebagai kelompok. Kelompok teman sebaya memiliki aturan tertentu yang harus dipatuhi oleh remaja sebagai anggota kelompoknya. Penyesuaian remaja terhadap norma dengan berperilaku sama dengan kelompok teman sebaya disebut konformitas.

Terdapat konformitas dari orang-orang sekitar yang menyukai K-Pop. Lebih lagi yang menjadi pasar dari musik ini kebanyakan adalah kalangan remaja, dimana dalam masanya mereka akan lebih cenderung konform pada teman-temannya (Ulfa, 2017) Hal ini sesuai dengan ciri dari seorang remaja dimana remaja ingin kehadirannya diakui sebagai bagian dari komunitasnya. Remaja juga menempatkan teman sebaya sebagai bagian penting dalam perkembangan dirinya (Sarwono, 2020) Oleh karena itu remaja akan berusaha untuk menyamakan dirinya dengan kelompok teman sebaya baik dari pakaian, perilaku, hingga gaya hidup. Konformitas pada remaja umumnya terjadi karena mereka tidak ingin dipandang berbeda dari teman-temannya dan demi memperoleh persetujuan, atau menghindari celaan kelompok. Konformitas dibagi dalam 3 tingkat diantaranya menurut Hurlock (1999) membagi konformitas yang dilakukan remaja terhadap teman sebaya ke dalam tiga tingkatan, 
yakni sebagai berikut. (1) Developmentally Appropiate Conformity. Merupakan bentuk penyesuaian yang dilakukan oleh remaja terhadap standar atau aturan-aturan yang telah ditetapkan oleh kelompok tanpa membuat dirinya kehilangan identitas. Remaja dengan tingkat konformitas yang tepat tidak mengorbankan individualitasnya dalam melakukan tindakan penyesuaian; (2) Lack of Conformity. Merupakan bentuk ketidak mampuan remaja dalam melakukan penyesuaian baik tingkah laku atau pendapat terhadap standar atau aturan yang telah ditetapkan oleh kelompok, sehingga rentan mengakibatkan penolakan sosial dari kelompok tersebut; (3) Over Conformity. Merupakan konformitas yang berlebihan, yaitu bentuk penyesuaian baik berupa tingkah laku, pemikiran ataupun pendapat terhadap aturanaturan yang telah ditetapkan oleh kelompok secara berlebihan sehingga menyebabkan remaja kehilangan identitas.

Salah satu alasan utama remaja melakukan konformitas adalah demi memperoleh persetujuan atau menghindari celaan kelompok. Pengaruh teman ini dapat dilihat pada perilaku, minat, dan pembicaraan. Remaja yang tidak kuat melawan tekanan dari teman temannya untuk menerima norma yang berlaku dikelompok cenderung akan mengikuti ataupun dengan terpaksa mengikuti gaya hidup kelompoknya dan mengasumsikan segala produk yang digunakan kelompoknya . Hal ini sesuai dengan ciri dari seorang remaja dimana remaja ingin kehadirannya diakui sebagai bagian dari komunitasnya. Remaja juga menempatkan teman sebaya sebagai bagian penting dalam perkembangan dirinya. Konsep konformitas seringkali digeneralisasikan untuk masa remaja karena dari banyak penelitian terungkap, salah satunya adalah penelitian menemukan bahwa pada masa remaja konformitas terjadi dengan frekuensi yang lebih tinggi dibandingkan dengan masa pertumbuhan lainnya. (Surya, 1997) Hal tersebut dapat dimengerti mengingat pada masa remaja proses pemantapan diri sedang berlangsung sehingga remaja akan lebih rentan terhadap pengaruh perubahan dan tekanan yang ada disekitarnya.

Selain itu hasil penelitian Almaida menemukan bahwa perilaku pemujaan selebriti pada subjek penggemar K-Pop juga memiliki hubungan positif yang signifikan dengan gejala depresi (Gumelar et al., 2021) Hal ini seiring dengan hasil penelitian Nurohmah \& Prakoso (2019) yang menemukan bahwa perilaku pemujaan selebriti pada penggemar boygroup EXO memiliki hubungan yang negatif dengan kesejahteraan psikologis. Artinya, semakin tinggi tingkat pemujaan selebriti, semakin rendah kesejahteraan psikologisnya. Hasil penelitian lain yang dilakukan oleh Khairunnisa (2019) yang menunjukkan bahwa penggemar Korean wave cenderung lebih individual dan memilih untuk bergaul dengan teman yang sama-sama 
menyukai dunia Korean wave. Subjek juga merasa bahwa ia sulit untuk mengutarakan perasaannya kepada orang lain. Ketika memiliki masalah subjek cenderung memilih diam memendam perasaannya atau menangis.

Dengan berbagai faktor penyebaran Korea Wave mengakibatkan terkhususnya pada anak muda lebih tertarik dan mengagung-agungkan k-pop dibandingkan Negara sendiri. Dan dari sinilah terdapat berbagai dampak negatif atau positif yang dialami remaja saat ini. Menurut (L. A. Putri, 2020) ada dampak positif maupun negatif jika remaja ikut terlibat dalam korean wave. Faktor positif yang bisa diambil dari perkembangan k-pop yang pesat ini diantaranya adalah:

1. K-pop menjadi inspirasi di dunia fashion banyaknya anak muda yang mempunyai kamauan besar untuk mengetahui hal-hal yang berbau korea sehingga menyebabkan mereka terinspirasi untuk mencontoh atau meniru cara berpakaian, cara mengetahui perpaduan mode dari idol yang mereka kagumi .

2. Mengetahui Citra Dirinya sehingga gambaran yang dimiliki seseorang terhadap dirinya sendiri sebagai ciptaan yang memilik fisik yang dikaitkan dengan karakteristik fisik dalam penampilan seseorang tersebut secara umum atau pemikiran seseorang tentang pandangan orang lain terhadap dirinya dan bagaimana orang menilai dirinya

3. Dapat bersosialisasi dan mandiri dengan adanya dunia k-pop ini sehingga remaja dapat lebih kreatif dalam mengembangkan dirinya. Dengan adanya hubungan pertemanan, mereka menjadi memiliki banyak teman dari berbagai daerah, atau pun dari Negara luar karea sesama penggemar idol yang dikagumi Seperti belajar mendiri dengan berani membuka online shop dengan menjual hal-hal berbau k-pop seperti pakaian, kosmetik, dan lainnya, dengan keuntungan dari penjualan online bisa membuat seseorang jadi mandiri.

4. Dapat memotivasi dan semangat, karena dengan mengagumi hal yang berbau korea dari situ memunculkan minat sehingga otomatis ada perasaan ingin belajar memahami bahasa korea tersebut sehingga dapat memperluas tambahan bidang kuasa bahasa asing karena dari minat memuncukan motivasi yang dapat membangkitkan dan mendorong seseorang untuk lebih bersemangat mencapai tujuan.

5. Manfaat secara emosional dapat membuat senang, menghilangkan stress bagi remaja yang lelah dari pekerjaan rumah atau tugas dari sekolah. Sebagai elemen yang memberikan rasa nyaman ia dapat dimanfaatkan, dapat dinikmati, selain sebagai pemberi rasa tersebut, juga sebagai pendorong untuk maju dalam kehidupan. 
Selain dampak positif adapun dampak negatif yang disebabkan oleh pengaruh Korean wave tersebut seperti:

1. Sikap fans yang berlebihan yang ditunjukkan oleh para penggemar atau fans terhadap idolanya ternyata bisa dikategorikan sebagai gangguan psikologis. menggemari sosok atau artis bukan tindakan yang salah. Namun hal itu menjadi masalah jika sudah terlampau berlebihan dan tidak rasional dalam memperlakukan sang idola.

2. Terjadi fanatisme terhadap remaja tersebut Fanatisme sangat fenomena pada zaman modern ini, realitas pribadi social dari masyarakat, karena pada saat ini berpengaruh pada seorang individu sehingga menciptakan kepercayaan dan pemahaman berupa pengabdian, hubungan, kesetiaan, kecintaan (Seregina et al., 2011)

3. Timbul sikap peniruan terhadap citra diri yang berlebihan pengaruh dari tayangan drama korea yang menarik perhatian public terutama remaja sehingga menimbulkan pengimitasian. Hal ini dibuktikan dengan adanya gaya hidup dan mengoleksi hal yang berbau K-pop, serta dalam peniruan penampilan fisik dari citra hidup dirinya (Kaparang, 1997). Dengan peniruan ini sehingga remaja tersebut akan meniru sedemikian mungkin khususnya bagi perempuan. Mereka akan mengikuti fashion dengan menggunakan baju yang kurang layak untuk dipakai. Bertentangan sekali dengan negra kita yang sebagian besar mengenut agama islam (Tartila, 2013).

4. Konformitas, Konformitas yaitu suatu prilaku tertentu yang dilakukan karena pengaruh orang lain atau kelompoknya untuk melakukan prilaku dan tindakan yang sama. Maka individu tersebut melakukannya baik menyukainnya atau tidak menyukai apa yang dia lakukan yang sedang terjadi (Sears, Freedman, \& Peplau, 1994). Konformitas tidak hanya pada prilaku dan tindakan yang dipengaruhi orang lain tetapi individu itu juga bertindak dan berpikir secara berbeda dari apa yang dilakukannya jika seorang diri (Myers, 2012).

5. Membuang waktu dan uang untuk hal yang sia-sia Terkadang remaja lupa akan waktu yang telah terbuang karana terlena akan keinginan melihat idolanya sehingga menyebabkan lupa belajar, lupa istirahat gara-gara nonton drama korea, dan membuang uang karena membeli hal-hal yang tidak berguna dan kadang cenderung membeli kuota internet yang berlebihan hanya untuk menstalking idolanya.

6. Kesehatan mata karena sering kali melihat ponsel. Layar ponsel memancarkan cahaya yang dapat mengganggu kesehatan mata jika ditatap dalam durasi waktu lama. Alasannya, ponsel bekerja menggunakan gelombang elektromagnetik dan jika 
terpapar terlalu lama dapat menyebabkan mata menjadi kering, panas, berair, memerah, bahkan katarak.

7. Insomnia atau kesulitan tidur karena sudah terlalu sering bergadang hanya untuk meraton menonton drama yang disukai. Hal ini tentu sangat menyita waktu istirahat seorang individu tersebut. Kurang tidur yang terus menerus dapat mengakibatkan rusaknya sel otak sehingga dapat menimbulkan gannguan pada kepala, seperti pusing ataupun sakit kepala. Hal ini dikarenakan otak kurang mendapatkan waktu untuk istirahat.

8. Efek dari budaya k-pop ini juga mempengaruhi anak dalam berpakain terutama untuk perempuan yang ingin mencontoh apa pakaian yang dipakai oleh idolanya. Kadang mereka memakai baju yang sangat tidak sopan dan ini bertentangan sekali dengan agama apalagi Indonesia yang didominasi oleh agama islam.untuk itu perlu perhatian dari orang tua untuk mengawasi dan mengontrol anaknya.

Berdasarkan pemaparan diatas jika penulis bandingkan antara dampak positif dan negatif lebih banyak berpengaruh pada dampak yang negatif, maka dari itu penulis tertarik untuk melakukan penelitian tentang perilaku fanatisme dan konformitas Korean wave pada remaja. Dikarenakan Remaja harus bisa merevolusi mental dan juga menjadi agent of change untuk membuat Indonesia semakin baik, dan sebuah bagian masa dari perjalanan kehidupan yang utuh yaitu bagian dari masyarakat yang senantiasa bisa melakukan banyak konstribusi kebaikan, ditinggikan, optimistis dan pandai. Remaja adalah generasi yang selalu ditunggu suara kritisnya dan diharapkan mampu membawa angin segar kehidupan untuk melakukan banyak perubahan dalam hal kebaikan. Tujuan yang hendak dicapai dalam tulisan ini adalah untuk mengetahui bagaimana perilaku fanatisme dan konformitas yang terjadi pada penggemar Korean wave pada kalangan remaja dan mendiskripsikan kondisi dampak negatif merebaknya perilaku fanatisme dan konformitas pada penggemar Korean wave pada remaja. Setelah membaca jurnal ini akan memberikan manfaat bagi peneliti, diharapkan dapat menambah wawasan dan masukan pada penelitian selanjutnya, serta agar semua pihak dapat mengerti tentang betapa pentingnya wawasan mengenai dampak negatif akibat dari perilaku fanatisme dan konformitas korean wave yang terjadi pada kalangan remaja dan manfaat bagi masyarakat yaitu sebagai pemahaman bahwa bagaimana dampak negatif bagi masyarakat. 


\section{METODE}

Metode yang digunakan dalam penelitian ini adalah metode SLR (Systematic Literature Review). Metode ini peneliti lakukan dengan mengidentifikasi, mengkaji, mengevaluasi serta menafsirkan semua penelitian yang tersedia. Dengan metode ini peneliti melakukan review dan mengidentifikasi jurnal-jurnal secara sistematis yang pada setiap prosesnya mengikuti langkah-langkah yang telah ditetapkan (Triandini, Jayanatha, Indrawan, Putra, \& Iswara, 2019).

Berdasarkan dari tahapan-tahapan di atas maka peneliti mencari artikel jurnal yang dengan kata kunci fanatisme dan konformitas pada Korean wave. Pengumpulan data dilakukan dengan mendokumentasi semua artikel yang diperoleh pada laporan penelitian ini. Artikel yang digunakan pada penelitian ini sebanyak 9 artikel jurnal dan 10 tahun terakhir dari google scholar. Artikel yang dipilih adalah artikel yang memiliki penelitian serupa lalu artikel dianalisis dan dirangkum. Hasil penelitian kemudian dijadikan kedalam satu pembahasan yang utuh pada artikel ini.

\section{HASIL}

\begin{tabular}{|c|c|c|}
\hline Peneliti & Judul penelitian & Hasil Penelitian \\
\hline $\begin{array}{l}\text { (Rofifah Yumna, } \\
\text { 2020) }\end{array}$ & $\begin{array}{l}\text { Aktivitas Fanatisme K-Pop } \\
\text { di Media Sosial (Analisis } \\
\text { Tekstual pada } \\
\text { AkunTwitter@Wingsforx1) }\end{array}$ & $\begin{array}{l}\text { Aktivitas yang dilakukan penggemar secara } \\
\text { berlebihan akan mengakibatkan seseorang menjadi } \\
\text { fanatik terhadap sesuatu. Fanatisme merupakan } \\
\text { sebuah keyakinan terhadap objek fanatik yang } \\
\text { dikaitkan dengan sesuatu yang berlebihan pada } \\
\text { suatu objek, sikap fanatik ini ditunjukkan dengan } \\
\text { aktivitas, rasa antusias yang ekstrem, keterikatan } \\
\text { emosi dan rasa cinta dan minat yang berlebihan } \\
\text { yang berlangsung dalam waktu yang lama (Eliani, } \\
\text { Yuniardi, \& Masturah, 2018). }\end{array}$ \\
\hline $\begin{array}{l}\text { (Made et al., } \\
\text { 2019) }\end{array}$ & $\begin{array}{l}\text { Perilaku Remaja Penggemar } \\
\text { Korean Wave : Systematic } \\
\text { Review }\end{array}$ & $\begin{array}{l}\text { Teridentifikasi berbagai perilaku penggemar } \\
\text { Korean wave. Dari } 9 \text { artikel, terdapat beberapa } \\
\text { artikel yang membahas perilaku penggemar } \\
\text { Korean Wave antara lain perilaku agresif }(n=2) \text {, } \\
\text { aktivitas fandom }(n=1) \text {, membuat fan fiction }(n=2) \text {, } \\
\text { sifat kosnumtif }(n=4) \text {, perubahan gaya hidup dan } \\
\text { pola makan }(n=3) \text {, sikap seksualitas }(n=3) \text {, dan } \\
\text { Roleplay }(n=1) \text {. }\end{array}$ \\
\hline (Widarti, 2016) & $\begin{array}{l}\text { Konformitas dan Fanatisme } \\
\text { Remaja Kepada Korean Wave } \\
\text { (Studi Kasus pada Komunitas } \\
\text { Penggemar Grup Musik CN } \\
\text { Blue) }\end{array}$ & $\begin{array}{l}\text { Mereka melakukan konformitas didasari atas sikap } \\
\text { pemujaan terhadap sang artis yang begitu tinggi } \\
\text { sampai seolah ada bisikan agar cara berpakaian } \\
\text { dan tindak tanduk sesuai dengan sang idola. Dari } \\
\text { sini konformitas tadi menimbulkan hasrat ingin }\end{array}$ \\
\hline
\end{tabular}




\begin{tabular}{|c|c|c|}
\hline & & $\begin{array}{l}\text { disukai oleh sesama penggema CN Blue pada } \\
\text { khusunya dan penggemar K-Pop pada umumnya. } \\
\text { Dalam konteks teori ini disebut sebagai sosial } \\
\text { normatif (keinginan untuk disukai). Hasrat } \\
\text { keinginan agar diterima secara sosial yaitu } \\
\text { penerimaan orang lain sesama penggemar CN Blue } \\
\text { terhadap diri serta pengharapan perlakuan positif } \\
\text { dari mereka. Konformitas juga bisa jadi upaya para } \\
\text { penggemar agar tidak diejek atau terhindar dari } \\
\text { bully sesama penggemar grup musik CN Blue. }\end{array}$ \\
\hline $\begin{array}{l}\text { (Nurfadiah \& } \\
\text { Yulianti, 2017) }\end{array}$ & $\begin{array}{l}\text { Konformitas dengan } \\
\text { Kepercayaan Diri pada } \\
\text { Remaja Komunitas Pecinta } \\
\text { Korea di Pekanbaru }\end{array}$ & $\begin{array}{l}\text { Hasil penelitian menunjukkan bahwa ada } \\
\text { hubungan antara konformitas dengan kepercayaan } \\
\text { diri pada remaja komunitas pecinta korea. } \\
\text { Berdasarkan hasil analisis kolerasi, pada penelitian } \\
\text { ini menunjukkan bahwa, ada hubungan antara } \\
\text { konformitas dengan kepercayaan diri pada remaja } \\
\text { komunitas pecinta korea, dengan hasil koefisien } \\
\text { korelasi (r) sebesar } 0.222 \text { dan hasil signifikansi (p) } \\
0,010 \text { (memenuhi p } \leq 0,01 \text { ) yang artinya hasil } \\
\text { penelitian menunjukkan bahwa ada hubungan } \\
\text { antara kepercayaan diri dengan konformitas. } \\
\text { Adapun hubungan antara kepercayaan diri dengan } \\
\text { konformitas positif. Semakin tinggi konformitas } \\
\text { semakin tinggi kepercayaan diri. }\end{array}$ \\
\hline $\begin{array}{l}\text { (Pertiwi et al., } \\
2013 \text { ) }\end{array}$ & $\begin{array}{l}\text { Konformitas dan Fanatisme } \\
\text { pada Remaja Korean Wave }\end{array}$ & $\begin{array}{l}\text { Berdasarkan hasil wawancara dari ketiga subjek, } \\
\text { mereka mengetahui tentang fenomena Korean } \\
\text { Wave dan ini terjadi karena penggaruh kebudayaan } \\
\text { dimasyarakat. Menurut Gunjoo dan Paik (2012) } \\
\text { Korean Wave merupakan gelombang kebudayaan } \\
\text { Korea yang merupakan gabungan dari tradisional } \\
\text { kebudayaan Korea dan budaya barat, dalam bahasa } \\
\text { Korea disebut dengan Hallyu., Korean Wave } \\
\text { berkisar dari drama televisi, film, musik populer } \\
\text { (K-Pop), tarian, video game sejauh, makanan, } \\
\text { fashion, pariwisata, dan bahasa (Hangul). } \\
\text { Berdasarkan dari hasil observasi keseluruhan } \\
\text { penelitian bahwa subjek merupakan penggemar } \\
\text { Korean Wave banyak mengkoleksi film-film dan } \\
\text { dramadrama Korea terbaru, bahkan jumlahnya } \\
\text { sangat banyak, subjek terlibat sebagai fans } \\
\text { boyband Super Junior dan banyak sekali } \\
\text { mengkoleksi pernak-pernik atribut idola seperti } \\
\text { poster, album original, stiker, gantungan kunci, } \\
\text { mug, album photo, majalah, tabloid, terdapat } \\
\text { koleksi variety show artis idola seperti Super } \\
\text { Junior dan artis yang lain dan sebagainya, subjek } \\
\text { sangat mengidolakan boyband Super Junior } \\
\text { bahkan rela dari kota Samarinda untuk pergi ke } \\
\text { Jakarta untuk nonton konser Super Junior dan ini }\end{array}$ \\
\hline
\end{tabular}




\begin{tabular}{|c|c|c|}
\hline & & $\begin{array}{l}\text { terbukti dari hasil pengamatan ketika subjek } \\
\text { menunjukkan potongan tiket konser yang pernah } \\
\text { dirinya tonton dan masih dirinya simpan sampai } \\
\text { sekarang sebagai kenang-kenangan. }\end{array}$ \\
\hline $\begin{array}{l}\text { (Fachrosi } \\
\text { et al., } \\
2020)\end{array}$ & $\begin{array}{lr}\text { Dinamika } & \text { Fanatisme } \\
\text { Penggemar } & \text { K-Pop pada } \\
\text { Komunitas } & \text { BTS-Army } \\
\text { Medan } & \end{array}$ & $\begin{array}{l}\text { Subjek pertama, C berusia } 20 \text { tahun merupakan } \\
\text { seorang mahasiswi. Ia sangat antusias ketika } \\
\text { diwawancarai. Kisah subjek C menunjukkan ia } \\
\text { menyukai grup BTS berawal dari kesukaannya } \\
\text { untuk menonton di kanal youtube. Sebelum } 2015 \text {, } \\
\text { ia merupakan penggemar musik KPop namun } \\
\text { semenjak berkenalan dengan musik BTS ia } \\
\text { langsung menyukai dan merasa tergila-gila dengan } \\
\text { boyband tersebut. Mulanya ia menyukai salah satu } \\
\text { figur dari ke tujuh anggota boyband tersebut. } \\
\text { Ketertarikan ini muncul menyeluruh ke setiap } \\
\text { anggota dikarenakan keterampilan suara dan tarian } \\
\text { yang membuat irama musik tersebut nyaman untuk } \\
\text { dinikmati. }\end{array}$ \\
\hline $\begin{array}{l}\text { (L. A. Putri, } \\
\text { 2020) }\end{array}$ & $\begin{array}{l}\text { Dampak Korea Wave } \\
\text { Terhadap Prilaku Remaja di } \\
\text { Era Globalisasi }\end{array}$ & $\begin{array}{l}\text { Seiring dengan meningkatnya popularitas Korea } \\
\text { wave di dunia internasional sangat mempengaruhi } \\
\text { kehidupan masyarakat di dunia Internasional. } \\
\text { Pengaruh korea wave di dunia internasional tak } \\
\text { terkecuali juga di Indonesia. 'Korean Wave' atau } \\
\text { 'Hallyu' yang sekarang sangat berpengaruh di } \\
\text { Indonesia terutama dikalangan remaja (Wijayanti, } \\
\text { 2012). }\end{array}$ \\
\hline $\begin{array}{l}\text { (K. A. Putri et } \\
\text { al., 2019) }\end{array}$ & $\begin{array}{l}\text { Korean Wave dalam } \\
\text { Fanatisme dan Konstruksi } \\
\text { Gaya Hidup Generasi Z }\end{array}$ & $\begin{array}{l}\text { Setiap individu memiliki penafsiran masing-masing } \\
\text { terhadap suatu hal yang ia lihat atau rasakan. } \\
\text { Korean Wave sebagai sebuah hiburan yang pada } \\
\text { hakikatnya dinikmati oleh khalayak luas pun } \\
\text { memiliki penilaian tersendiri di mata tiap individu. } \\
\text { Berdasarkan hasil penelitian dengan seluruh } \\
\text { informan yang merupakan Generasi Z1, mereka } \\
\text { memiliki sudut pandang yang serupa dalam } \\
\text { memandang dan menilai Korean Wave. Satu poin } \\
\text { yang mendasar dalam penafsirkan Korean Wave } \\
\text { adalah menganggap hal tersebut sebagai sebuah } \\
\text { hiburan dalam kehidupan mereka masing-masing. } \\
\text { Penyebaran Korean Wave memang sangat } \\
\text { memanfaatkan peran teknologi informasi seperti } \\
\text { media sosial. Sasarannya pun sangat tepat dan } \\
\text { akurat, yaitu kalangan remaja Generasi Z, dimana } \\
\text { pada usia tersebut mereka begitu akrab dengan } \\
\text { gadget dan internet. Berawal dari rasa penasaran } \\
\text { yang timbul pada diri masing-masing, mereka mulai } \\
\text { mencari tahu lebih dalam mengenai apa itu Korean } \\
\text { Wave. }\end{array}$ \\
\hline $\begin{array}{l}\text { (Rinata \& Dewi, } \\
\text { 2019) }\end{array}$ & $\begin{array}{l}\text { Fanatisme Penggemar K-Pop } \\
\text { dalam Bermedia Sosial di }\end{array}$ & $\begin{array}{l}\text { Hasil penelitian menunjukkan bahwa perilaku } \\
\text { Fanatisme penggemar tidak hanya terlihat dari }\end{array}$ \\
\hline
\end{tabular}




\begin{tabular}{|l|l|l|}
\hline Instagram. & $\begin{array}{l}\text { seberapa jauh mereka menggemari idola Korea } \\
\text { tetapi juga dalam bermedia sosial, hal tersebut }\end{array}$ \\
& terlihat dari berbagai aktivitas yang telah \\
& dilakukannya di Instagram serta respon fans K-pop \\
dalam menyikapi informasi hoax dan negatif dari & idola K-pop.
\end{tabular}

Tabel 1. Hasil Penelitian

Hasil penelitian menunjukkan fanatisme dan konformitas Korean wave pada Remaja yang membentuk perilaku kesetiaan yang tergabung dalam kelompok atau komunitas, dukungan perhatian yang ditunjukkan, dan keyakinan atau pandangan yang menonjol tentang objek Remaja yang menggemari. Korean Wave bisa diupayakan tidak berperilaku fanatik dan konformitas yang negatif seperti berperilaku ekstrim kepada idola, membuat komunitas dengan ciri khas kegemaran yang sama pada Korean wave dan jadikanlah perilaku fanatik dan konformitas remaja yang positif agar masyarakat dapat menerima hal tersebut.

\section{PEMBAHASAN}

Budaya Korean wave paling terkenal dikalangan anak muda, budaya ini terdiri dari musik korea (K-pop), drama (K-drama), film, gaya busana, makanan dan kecantikan. Remaja atau bisa disebut sebagai anak muda memiliki kegemaran masing-masing dalam menentukan idola mereka, seperti halnya musik Pop Korea yang banyak digemari membuat banyak memiliki penggemar setia pada setiap boyband dan girlband yang bisa menimbulkan fansclub tersendiri. Dari komunitas fans-club tersebut menunjukkan bahwa terdapat pengaruh budaya korea terhadap perubahan perilaku remaja. Perubahan perilaku yang dimaksud seperti remaja rela menghambur-hamburkan uang dan mengikuti gaya hidup budaya tersebut seperti mengenakan pakaian dan memiliki hal yang sama dengan idolanya.

Pengaruh adanya komunitas fans-club ada factor yang memperkuat terbentuknya fans-club yaitu adanya perilaku Konfomitas pada remaja penggemar Korean wave dilakukan terhadap aspek fashion dan gaya hidup seperti mereka mencontoh cara berfash-ion budaya korea mulai dari gaya rambut dan melakukan konformitas didasari atas sikap pemujaan terhadap sang artis yang begitu tinggi sampai seolah ada bisikan agar cara berpakaian dan tindak tanduk sesuai dengan sang idola. Namun, ada satu hal yang tidak remaja ikuti yaitu tindakan dengan hal-hal yang bersifat keyakinan. Perilaku konformitas bisa menimbulkan hasrat ingin disukai oleh sesama penggemar Korean. Remaja berharap ada perlakuan positif dari teman-temannya, dengan perilaku konformitas bisa menjadi upaya para remaja agar tidak diejek atau terhindar dari bully sesama penggemar Korean wave. Seiring berkembangnya 
sebuah kebiasaan dari komunitas yang dikuatkan dengan perilaku konformitas agar remaja dapat diterima dilingkungan teman sebaya maka akan muncul menjadi perilaku fanatisme sebagai penggemar Korean Wave dan tidak hanya terlihat dari seberapa jauh mereka menggemari idola Korea tetapi juga dalam bermedia sosial, hal tersebut terlihat dari berbagai aktivitas yang telah dilakukannya di Instagram serta respon fans K-pop dalam menyikapi informasi hoax dan negatif dari idola K-pop.

Adapun dampak dari fanatisme yang tidak sehat ini terkadang membuat mereka tidak berpikir jernih dalam melakukan dan menentukan pilihan. Pada umumnya, orang yang memiliki pandangan fanatik merasa tidak membutuhkan nasihat dari orang lain selain dari sesama dari mereka, atau dalam kasus ini adalah sesama penggemar Korean wave.

Berdasarkan uraian diatas perlu adanya solusi agar terminimalisir dampak negatif dari fanatisme dan konformitas Korean wave pada remaja sehingga dapat membantu penggemar Korean wave untuk memahami dalam menghadapi dampak negatif yang ditimbulkan dari fanatisme dan konformitas Korean wave pada remaja.

Berdasarkan hasil penelitian dari (Nurfadiah \& Yulianti, 2017) menunjukkan bahwa ada hubungan antara konformitas dengan kepercayaan diri pada remaja komunitas pecinta korea. Hasil penelitian menunjukkan bahwa ada hubungan antara kepercayaan diri dengan konformitas. Adapun hubungan antara kepercayaan diri dengan konformitas positif. Semakin tinggi konformitas semakin tinggi kepercayaan diri. Maka dari itu remaja harus mampu menciptakan sebuah konformitas komunitas yang positif seperti keterlibatan remaja dengan sebuah organisasi yang bisa membuat remaja lebih berkembang, dan dengan mengajak juga terlibat dalam kegiatan-kegiatan yang positif sehingga dari kegiatan yang positif mampu membentuk karakter remaja menjadi lebih percaya diri. Selain itu dalam hal kaitannya dengan perilaku fanatisme pada remaja menurut (Desain \& Seni, 2020) perilaku fanatik harus dibimbing dengan pendekatan untuk memperdebatkan dan memodifikasi pemikiran yang irasional sehingga mampu berpikir lebih rasional, serta menunjukkan contoh-contoh yang sudah terjadi pada komunitas yang dia ikuti. Apalagi jika ada contoh yang berakhir negatif seperti kekacauan, kegagalan, ataupun penjara. Terlebih, orang yang fanatik tidak suka jika diberi nasihat oleh seseorang yang berada diluar lingkarannya atau komunitasnya, sehingga akan lebih efektif jika orang yang membimbing tersebut adalah sesama penggemar Korean wave yang akan mempunyai pengalaman dan perasaan yang sama. Oleh karena itu butuh suatu kesadaran yang lebih dari para remaja penggemar Korean wave bahwa perilaku 
konformitas dan fanatisme pada Korean wave memiliki dampak yang bisa merugikan dirinya sendiri.

\section{SIMPULAN}

Korean Wave adalah sebuah istilah yang diberikan untuk tersebarnya budaya Pop Korea secara global di berbagai negara di dunia tidak terkecuali di negara Indonesia, Di Indonesia saat ini, fenomena Korea melanda generasi muda terutama remaja Indonesia yang umumnya menyenangi Korean wave. Fenomena budaya populer Korea yang melahirkan konformitas dan fanatisme pada Korean Wave hal ini karena sikap remaja yang terkadang lebih mengagungkan budaya populer Korea dari pada budaya dalam negeri, hal ini menunjukkan bahwasanya budaya Pop Korea secara tidak disadari telah menimbulkan fenomena dikalangan remaja.

Dampak yang disebabkan oleh perkembangan Korean wave ini diantaranya ada yang positif ada juga negatif. Dampak positif diantaranya adalah Kpop menjadi inspirasi di dunia fashion, mengetahui Citra Dirinya, dapat bersosialisasi dan mandiri dengan adanya dunia kpop ini sehingga remaja dapat lebih kreatif dalam mengembangkan dirinya., dapat bersosialisasi karena dengan mereka yang memiliki sifat yang sama, dapat memotivasi belajar memahami bahasa korea yang memperluas tambahan bidang kuasa bahasa asing, dan manfaat secara emosional dapat membuat senang.

Disamping dampak positif tentu juga ada dampak negatifnya diantaranya adalah timbul sikap fans yang berlebihan, terjadi fanatisme, timbul sikap terhadap citra diri yang berlebihan, konformitas, membuang waktu dan uang untuk hal yang sia-sia, kesehatan mata karena sering kali melihat ponsel, insomnia dan kadang efek dari budaya k-pop ini juga mempengaruhi anak dalam berpakain terutama untuk perempuan yang ingin mencontoh apa pakaian yang dipakai oleh idolanya.

Saran dari penulis perlu perhatian dari orang tua untuk mengawasi dan mengontrol anak remajanya supaya bisa menghindari perilaku yang mengidolakan Korean wave secara berlebihan, bagi remaja yang menggemari Korean Wave bisa diupayakan tidak berperilaku fanatik dan konformitas yang negatif seperti berperilaku ekstrim kepada idola, tidak membuat komunitas dengan ciri khas kegemaran yang sama pada Korean wave dan jadikanlah perilaku fanatik dan konformitas remaja yang positif agar masyarakat dapat menerima hal tersebut dan dapat membuahkan banyak manfaat baik untuk diri sendiri maupun orang lain. 


\section{DAFTAR RUJUKAN}

Fachrosi, E., Fani, D. T., Lubis, R. F., Aritonang, N. B., Azizah, N., Saragih, D. R., \& Malik, F. (2020). Dinamika Fanatisme Penggemar K-Pop pada Komunitas BTS-Army Medan. 6(2), 194-201.

Gumelar, S. A., Almaida, R., \& Laksmiwati, A. (2021). Dinamika psikologis fangirl K-Pop. 9(1), 17-24. https://doi.org/10.22219/cognicia.v9i1.15059

https://mediaindonesia.com/humaniora/324956/fanatisme-fans-berlebihan-termasuk-kategorigangguan-psikologis

Jannah, M. (2017). Remaja Dan Tugas-Tugas Perkembangannya Dalam Islam. Psikoislamedia : Jurnal Psikologi, 1(1), 243-256. https://doi.org/10.22373/psikoislamedia.v1i1.1493

Kaparang, O. (1997). ANALISA GAYA HIDUP REMAJA DALAM MENGIMITASI BUDAYA POP KOREA MELALUI TELEVISI. Acta Diuma Komunikasi Universitas Samratulangi, 13(5), 512-517.

Made, N., Wulansari, A., \& Telp, N. (2019). PENDAHULUAN Budaya pop korea atau Hallyu atau Korean wave adalah budaya yang terkenal dikalangan anak muda, budaya ini terdiri dari musik korea ( K-pop ), drama ( $K$-drama ), film, gaya busana , makanan dan kecantikan . Budaya ini berkembang di Asia Teng. 12(2), 13-24.

Nurfadiah, R. T., \& Yulianti, A. (2017). Konformitas dengan Kepercayaan Diri pada Remaja Komunitas Pecinta Korea di Pekanbaru. Psikoislamedia Jurnal Psikologi, 2(2), 212223.

Pertiwi, S. A., Psikologi, P. S., \& Samarinda, U. M. (2013). KONFORMITAS DAN FANATISME PADA REMAJA KOREAN WAVE. 1(2), 84-90.

Purwanti, S. (2013). Korea, remaja dan proses peniruan. Psikostudia: Jurnal Psikologi, 2(1).

Putri, K. A., Amirudin, A., \& Purnomo, M. H. (2019). Korean Wave dalam Fanatisme dan Konstruksi Gaya Hidup Generasi Z. Nusa: Jurnal Ilmu Bahasa Dan Sastra, 14(1), 125. https://doi.org/10.14710/nusa.14.1.125-135

Putri, L. A. (2020). Dampak Korea Wave Terhadap Prilaku Remaja Di Era Globalisasi. AlIttizaan: Jurnal Bimbingan Konseling Islam, 3(1), 42. https://doi.org/10.24014/0.8710187

Rinata, A. R., \& Dewi, S. I. (2019). Fanatisme Penggemar Kpop Dalam Bermedia Sosial Di Instagram. Interaksi: Jurnal Ilmu Komunikasi, $8(2), \quad 13$. https://doi.org/10.14710/interaksi.8.2.13-21

Rofifah Yumna, A. S. dan A. F. (2020). Aktivitas Fanatisme Kpop Di Media Sosial (Analisis Tekstual Pada Akun Twitter@Wingsforx1). Syntax Idea, Vol. 2, No. 5 Mei 2020, 02(9), 108.

Sarwono, S. W. (2020). Psikologi ulayat. Jurnal Psikologi Ulayat, 1(1), 1-16. https://doi.org/10.24854/jpu2

Sa'idah, I., Atmoko, A., \& Muslihati, M. (2021). Aspirasi Karier Generasi Milenial. Edu Consilium: Jurnal Bimbingan dan Konseling Pendidikan Islam, 2(1), 62-89.

Seregina, A., Koivisto, E., \& Mattila, P. (2011). Fanaticism - It's Development and Meanings in Consumers' Lives. Aalto University, 1-101.

Surya, F. A. (1997). Perbedaan Tingkat Konformitas Ditinjau Dari Gaya Hidup Pada Remaja. In Psikologika: Jurnal Pemikiran dan Penelitian Psikologi (Vol. 3, Issue 7). https://doi.org/10.20885/psikologika.vol3.iss7.art6

Tartila, P. L. (2013). FANATISME FANS KPOP DALAM BLOG NETIZENBUZZ. Commonline, 2(3), 190-205.

Triandini, E., Jayanatha, S., Indrawan, A., Werla Putra, G., \& Iswara, B. (2019). Metode Systematic Literature Review untuk Identifikasi Platform dan Metode Pengembangan 
Sistem Informasi di Indonesia. Indonesian Journal of Information Systems, 1(2), 63. https://doi.org/10.24002/ijis.v1i2.1916

Ulfa, U. A. (2017). Hubungan Antara Konformitas Teman Sebaya dan Gaya Hidup Konsumtif Dengan Kepercayaan Diri. Psikoborneo: Jurnal Ilmiah Psikologi, 5(4), $554-562$.

Widarti. (2016). Konformitas dan Fanatisme Remaja Kepada Korean Wave (Studi Kasus pada Komunitas Penggemar Grup Musik CN Blue). Jurnal Komunikasi, 7(2), 12-18. https://ejournal.bsi.ac.id/ejurnal/index.php/jkom/article/view/1486 